\title{
Sodium chloride salinity in fruit vegetable crops in soilless culture
}

\author{
C. SONNEVELD \& A. M. M. VAN DER BURG \\ Glasshouse Crops Research Station, P.O. Box 8, NL 2670 AA Naaldwijk, Netherlands
}

Received 19 December 1990; accepted 15 March 1991

\begin{abstract}
Tomato, cucumber and sweet pepper were grown in hydroponic systems in which the nutrient solutions were recirculated. The electrical conductivity (EC) of the nutrient solution was maintained at values of $2.5,3.7$ or $5.2 \mathrm{dS} \mathrm{m}^{-1}\left(25^{\circ} \mathrm{C}\right)$ in the different treatments. In some of the treatments, the EC values mentioned were achieved by addition of nutrients, and in others by addition of a combination of nutrients and $\mathrm{NaCl}$. Yields of all crops were adversely affected by increased EC values. Most fruit quality characteristics, on the contrary, were favourably affected. However, blossom-end rot increased at higher EC values. For sweet pepper, this was especially the case with $\mathrm{NaCl}$ addition. Apart from that, only slight specific $\mathrm{NaCl}$ effects were noticed. Salinity threshold values for the different crops lay between 2.3 and $3.5 \mathrm{dS} \mathrm{m}^{-1}$ and salinity yield decrease values ranged from 2.3 to $7.6 \%$ per $\mathrm{dS} \mathrm{m}^{-1}$. The absorption of $\mathrm{Na}$ and $\mathrm{Cl}$ differed with crop and with the $\mathrm{Na}$ and $\mathrm{Cl}$ concentration.
\end{abstract}

Keywords: Capsicum annuum, Cucumis sativus, EC, fruit quality, Lycopersicon esculentum, $\mathrm{NaCl}$, salinity threshold value, salinity yield decrease value

\section{Introduction}

In the Dutch greenhouse industry, soil salinity is a serious problem. Therefore, in former times when crops were grown in the greenhouse border soil, effects of soil salinity were studied in long standing research (Sonneveld, 1988a). At present, however, greenhouse fruit vegetable crops are mainly grown in soilless cultures, especially in rockwool slabs (Sonneveld, 1988b). This growing system differs widely from the traditional soil system. Therefore a study of salinity effects under these growing conditions was necessary.

The principal salinity problem in soilless cultures is the accumulation of $\mathrm{Na}$ and $\mathrm{Cl}$, as these elements are abundantly present in many irrigation waters, while these ions are only sparingly absorbed by most crops. Hence, accumulation of $\mathrm{Na}$ and $\mathrm{Cl}$ in the root environment occurs, and high concentrations can readily be effected in small root volumes as used in most soilless culture systems.

The object of the present study was to assess the maximum $\mathrm{Na}$ and $\mathrm{Cl}$ concentrations acceptable in soilless cultures. To this end equal electrical conductivity (EC) values were achieved in the root environment by addition of either nutrients only or 
a combination of sodium chloride and nutrients. In this way, information was gained about the possibility of a partial replacement of nutrients by $\mathrm{Na}$ and $\mathrm{Cl}$. The rather high $\mathrm{EC}$ value of $3 \mathrm{dS} \mathrm{m}^{-1}\left(25^{\circ} \mathrm{C}\right)$ maintained for fruit-vegetable crops (Sonneveld, 1988b) suggested the possibility of such a replacement, since the concentrations of nutrients added to achieve an EC value of $3 \mathrm{dS} \mathrm{m}^{-1}$ exceed those necessary for plant nutrition.

\section{Materials and methods}

\section{Experimental design}

EC values of $2.5,3.7$ and $5.2 \mathrm{dS} \mathrm{m}^{-1}$ in the root environment were compared. In three experiments, these values were realised by addition of different quantities of nutrient elements, keeping the ratios between the elements constant. The concentrations of $\mathrm{Na}$ and $\mathrm{Cl}$ were below $5 \mathrm{mmol}^{-1}$. In two other treatments, $\mathrm{EC}$ values of 3.7 and $5.2 \mathrm{dS} \mathrm{m}^{-1}$ were realised by addition of nutrients up to a level of 2.2 , while $\mathrm{NaCl}$ was added to achieve the EC value intended. To this end 12.5 and $25 \mathrm{mmol}$ $\mathrm{NaCl}$ per litre, respectively, were required.

The treatments were laid out in an experimental design of four blocks. Within each block the treatments were randomized independently. One experimental plot covered $5.5 \mathrm{~m}^{2}$ greenhouse area. One sweet pepper Capsicum annuum crop and two tomato Lycopersicon esculentum and cucumber Cucumis sativus crops were grown. Growing periods and cultivars used are listed in Table 1.

\section{Growing system}

The crops were grown in gutters placed on a slope of $1.5 \%$. The nutrient solutions used were continuously recirculated in these gutters. The young plants were raised in rockwool cubes of 0.41 . The tomato plants were placed in the gutter without substrate, like in a nutrient film system (Graves, 1983). Sweet pepper and cucumber were grown on rockwool strips placed in the gutters. The strips were $0.10-0.15 \mathrm{~m}$ wide and the height was between 0.075 and $0.10 \mathrm{~m}$.

The experiments were carried out in a heated greenhouse in which blueprint setpoints for heating and ventilation were maintained for the different crops. The recirculating nutrient solution was not heated.

Table 1. Growing periods of the crops after planting out and cultivars used.

\begin{tabular}{llll}
\hline Crop & \multicolumn{2}{l}{ Growing period } & Cultivar \\
Tomato (1) & Jul. 85 - Nov. 85 & Estafette \\
Tomato (2) & Jan. 86 - Sep. 86 & Turbo \\
Sweet pepper & Dec. 86 - Oct. 87 & Plutona \\
Cucumber (1) & Jan. 88 - May 88 & Ventura \\
Cucumber (2) & Aug. 88 - Oct. 88 & Corona \\
\hline
\end{tabular}




\section{Nutrient solution}

To achieve optimal nutrient concentrations in the root environment, the addition of nutrients was adjusted to crops and growing conditions. In the recirculating nutrient solutions at an EC value of $2.5 \mathrm{dS} \mathrm{m}^{-1}$ ion contents were maintained as standardized for the crops (Sonneveld \& Straver, 1989). To achieve these values during crop growth, on average the following ions were supplied: in $\mathrm{mmol}^{-1}$ water added: $\mathrm{NO}_{3} 10-13, \mathrm{H}_{2} \mathrm{PO}_{4} 1.0-1.25, \mathrm{SO}_{4} 1.0-1.5, \mathrm{NH}_{4} 1.0-1.25, \mathrm{~K} 6.0-6.5, \mathrm{Ca} 2.5-3.0, \mathrm{Mg}$ $1-1.25$; in $\mu \mathrm{mol} \mathrm{l}^{-1}$ : Fe 15, Mn 10, Zn 4-5, B 20-25, Cu 0.75, Mo 0.5. Simultaneous measurements in recirculating solutions and rockwool slabs made clear that EC values in solutions and slabs were equal.

\section{Crop observations}

At harvest, the numbers and the weights of marketable, deformed and blossom-end rot fruits were determined separately. The weights of the deformed and blossomend rot fruits were expressed as percentages of total fruit weight. Other fruit quality judgments carried out were dependent on the crop. Tomato shelf life was expressed as the number of days between colour stage $100 \%$ orange and fruit softening; russetting as an index between 0 and 5 for none and severely affected fruits, respectively; acids as mmol per $\mathrm{kg}$ puree and refraction as \% Brix. For sweet pepper, fruits affected by russetting and green spot were expressed as percentages of total fruit number and the vitamin $\mathrm{C}$ content was expressed as $\mathrm{mg} \mathrm{g}^{-1}$ fresh material. With cucumbers, fruit colour was judged using an index from 1 to 9 for the colour range from completely yellow to dark green, respectively, and shelf life was expressed as the number of days between harvest and colour stage 5 .

The storage temperature for the tomato and the cucumber fruits was $20^{\circ} \mathrm{C}$ and the relative humidity was between 80 and $90 \%$.

\section{$\mathrm{Na}$ and $\mathrm{Cl}$ absorption}

The solutions were analysed weekly for $\mathrm{Na}$ and $\mathrm{Cl}$, and the uptakes of these elements were calculated as mmol per litre of water absorbed, from the amounts of $\mathrm{NaCl}$ and water removed from the system.

\section{Results}

The marketable fruit yields were reduced by increasing EC value in all crops (Table 2). With tomato (crop 2) and sweet pepper, the yield reduction was brought about by a lower fruit number as well as a lower fruit weight. With tomato crop 1 the fruit weight was affected only. With cucumber the lower fruit number was a dominant factor in crop 1 only. High sodium chloride did not specifically affect the fruit yield of tomato. With sweet pepper and cucumber a tendency towards a specific effect was found, but this was significant only for the high EC value in the second cucumber crop. 
Table 2. Yields of marketable fruits given as number and $\mathrm{kg} \mathrm{m}^{-2}$. Average fruit weights (FrW) expressed in $\mathrm{g}$.

\begin{tabular}{|c|c|c|c|c|c|c|}
\hline \multirow[t]{2}{*}{ Treatment $\mathrm{EC} / \mathrm{NaCl}$} & Number & $\mathrm{kg} \mathrm{m}^{-2}$ & FrW & Number & $\mathrm{kg} \mathrm{m}^{-2}$ & FrW \\
\hline & \multicolumn{3}{|c|}{ Tomato crop 1} & \multicolumn{3}{|c|}{ Tomato crop 2} \\
\hline $2.5 / 5$ & 79 & 7.2 & 91 & 303 & 24.7 & 82 \\
\hline $3.7 / 5$ & 82 & 7.0 & 85 & 296 & 23.1 & 78 \\
\hline $3.7 / 12.5$ & 81 & 7.0 & 87 & 298 & 23.4 & 79 \\
\hline $5.2 / 5$ & 81 & 6.7 & 83 & 276 & 20.4 & 74 \\
\hline $5.2 / 25$ & 86 & 6.8 & 79 & 279 & 20.8 & 75 \\
\hline \multirow[t]{2}{*}{$L S D(0.05)$} & ns & 0.5 & 6 & 21 & 1.9 & 4 \\
\hline & \multicolumn{3}{|c|}{ Sweet pepper } & & & \\
\hline $2.5 / 5$ & 96 & 14.0 & 147 & & & \\
\hline $3.7 / 5$ & 96 & 13.5 & 141 & & & \\
\hline $3.7 / 12.5$ & 90 & 12.5 & 139 & & & \\
\hline $5.2 / 5$ & 85 & 11.7 & 138 & & & \\
\hline $5.2 / 25$ & 80 & 11.1 & 139 & & & \\
\hline \multirow[t]{2}{*}{$\operatorname{LSD}(0.05)$} & 9 & 1.3 & 4 & & & \\
\hline & \multicolumn{3}{|c|}{ Cucumber crop 1} & \multicolumn{2}{|c|}{ Cucumber crop 2} & \\
\hline $2.5 / 5$ & 50 & 24.7 & 498 & 20 & 10.2 & 523 \\
\hline $3.7 / 5$ & 47 & 23.0 & 494 & 20 & 10.0 & 513 \\
\hline $3.7 / 12.5$ & 45 & 22.3 & 496 & 20 & 10.2 & 510 \\
\hline $5.2 / 5$ & 43 & 20.7 & 486 & 20 & 9.9 & 506 \\
\hline $5.2 / 25$ & 41 & 20.3 & 495 & 17 & 8.6 & 512 \\
\hline$L S D(0.05)$ & 3 & 1.5 & ns & 2 & 1.0 & ns \\
\hline
\end{tabular}

With the data presented, salinity threshold values $(\mathrm{t})$ and salinity yield decrease $(S Y D)$ values were calculated by the following equations:

$$
\begin{aligned}
& \mathrm{t}=3.7\left(\mathrm{dS} \mathrm{m}^{-1}\right)-\frac{\left(\mathrm{Y}_{(2.5)}\right)-\mathrm{Y}_{(3.7)}(5.2-3.7)}{\mathrm{Y}_{(3.7)}-\mathrm{Y}_{(5.2)}}\left(\mathrm{dS} \mathrm{m}^{-1}\right) \\
& \mathrm{SYD}=\frac{\left(\mathrm{Y}_{(5.2)}-\mathrm{Y}_{(3.7)}\right) \times 100 \%}{\mathrm{Y}_{2.5}(5.2-3.7)\left(\mathrm{dS} \mathrm{m}^{-1}\right)}
\end{aligned}
$$

in which $Y_{(x)}$ is the fruit yield at the EC value indicated by $x$.

In the equations given, it is assumed that yield reductions above the salinity threshold value are linear (Maas \& Hoffman, 1977) and that the salinity threshold value is below a value of $3.7 \mathrm{dS} \mathrm{m}^{-1}$; this was confirmed by the data. Results of the calculation are listed in Table 3 .

The data of the different fruit quality characteristics are listed in Table 4. Blossom-end rot in tomato and sweet pepper increased with increasing EC values. In sweet pepper the disorder was specifically associated with high $\mathrm{NaCl}$. Apart from blossom-end rot, the external fruit quality was generally improved by increasing 
Table 3. Salinity threshold values ( $\mathrm{t}$ ) and salinity yield decrease values (SYD) of $\mathrm{kg}$ marketable fruit calculated from the data of Table 2.

\begin{tabular}{lll}
\hline Experiment & $\mathrm{t}\left(\mathrm{dS} \mathrm{m}^{-1}\right)$ & $\mathrm{SYD}\left(\%\right.$ per dS m $\left.\mathrm{m}^{-1}\right)$ \\
& & \\
Tomato crop 1 & 2.5 & 2.3 \\
crop 2 & 2.9 & 7.2 \\
Sweet pepper & 2.8 & 7.6 \\
Cucumber crop 1 & 2.3 & 5.8 \\
crop 2 & 3.5 & 5.6 \\
\hline
\end{tabular}

Table 4 . Fruit quality as affected by the treatments.

\begin{tabular}{|c|c|c|c|c|c|c|c|c|c|c|}
\hline \multirow{2}{*}{$\begin{array}{l}\text { Treatment } \\
\mathrm{EC} / \mathrm{NaCl}\end{array}$} & \multicolumn{5}{|c|}{ Tomato crop 1} & \multicolumn{5}{|c|}{ Tomato crop 2} \\
\hline & $\begin{array}{l}\text { BER } \\
(\%)\end{array}$ & $\begin{array}{l}\text { shelf } \\
\text { life } \\
\text { (days) }\end{array}$ & $\begin{array}{l}\text { russet- } \\
\text { ting } \\
\text { index }\end{array}$ & $\begin{array}{l}\text { acid } \\
(\mathrm{mmol} \\
\left.\mathrm{kg}^{-1}\right)\end{array}$ & $\begin{array}{l}\text { refrac- } \\
\text { tion } \\
(\%)\end{array}$ & $\begin{array}{l}\text { BER } \\
(\%)\end{array}$ & $\begin{array}{l}\text { shelf } \\
\text { life } \\
\text { (days) }\end{array}$ & $\begin{array}{l}\text { russet- } \\
\text { ting } \\
\text { index }\end{array}$ & $\begin{array}{l}\text { acid } \\
(\mathrm{mmol} \\
\left.\mathrm{kg}^{-1}\right)\end{array}$ & $\begin{array}{l}\text { refrac- } \\
\text { tion } \\
(\%)\end{array}$ \\
\hline $2.5 / 5$ & 3.9 & 11.1 & 1.18 & 69 & 5.1 & 1.9 & 7.7 & 2.3 & 68 & 4.7 \\
\hline $3.7 / 5$ & 9.9 & 13.8 & 0.77 & 71 & 5.4 & 2.1 & 9.5 & 2.2 & 74 & 5.1 \\
\hline $3.7 / 12.5$ & 5.5 & 14.6 & 0.72 & 72 & 5.2 & 1.9 & 7.8 & 2.3 & 73 & 5.0 \\
\hline $5.2 / 5$ & 7.9 & 16.5 & 0.56 & 75 & 5.5 & 3.1 & 9.3 & 1.8 & 70 & 4.9 \\
\hline $5.2 / 25$ & 8.2 & 16.5 & 0.45 & 78 & 5.6 & 3.0 & 9.8 & 1.7 & 74 & 5.1 \\
\hline $\operatorname{LSD}(0.05)$ & 2.5 & 1.7 & 0.21 & 4 & 0.3 & ns & 0.9 & 0.2 & 2 & 0.1 \\
\hline \multirow{2}{*}{$\begin{array}{l}\text { Treatment } \\
\mathrm{EC} / \mathrm{NaCl}\end{array}$} & \multicolumn{10}{|c|}{ Sweet pepper } \\
\hline & \multicolumn{2}{|l|}{$\begin{array}{l}\text { BER } \\
(\%)\end{array}$} & \multicolumn{2}{|c|}{$\begin{array}{l}\text { deformed } \\
(\%)\end{array}$} & \multicolumn{2}{|c|}{$\begin{array}{l}\text { russetting } \\
(\%)\end{array}$} & \multicolumn{2}{|c|}{$\begin{array}{l}\text { green spot } \\
(\%)\end{array}$} & \multicolumn{2}{|c|}{$\begin{array}{l}\text { vit C } \\
\left(\mathrm{mg} \mathrm{g}^{-1}\right)\end{array}$} \\
\hline $2.5 / 5$ & \multicolumn{2}{|l|}{2.1} & \multicolumn{2}{|l|}{3.1} & \multicolumn{2}{|l|}{23.0} & \multicolumn{2}{|l|}{7.2} & \multicolumn{2}{|l|}{1.94} \\
\hline $3.7 / 5$ & \multirow{2}{*}{\multicolumn{2}{|c|}{$\begin{array}{l}3.1 \\
7.5\end{array}$}} & \multicolumn{2}{|l|}{4.2} & \multicolumn{2}{|l|}{18.4} & \multicolumn{2}{|l|}{5.5} & \multicolumn{2}{|l|}{1.84} \\
\hline $3.7 / 12.5$ & & & \multirow{2}{*}{\multicolumn{2}{|c|}{$\begin{array}{l}4.9 \\
3.7\end{array}$}} & \multirow{2}{*}{\multicolumn{2}{|c|}{$\begin{array}{l}19.3 \\
18.4\end{array}$}} & \multirow{2}{*}{\multicolumn{2}{|c|}{$\begin{array}{l}3.7 \\
2.7\end{array}$}} & \multicolumn{2}{|l|}{1.70} \\
\hline $5.2 / 5$ & \multicolumn{2}{|l|}{7.0} & & & & & & & 2.10 & \\
\hline $5.2 / 25$ & \multicolumn{2}{|l|}{12.6} & \multicolumn{2}{|l|}{3.2} & \multirow{2}{*}{\multicolumn{2}{|c|}{$\begin{array}{r}14.7 \\
5.4\end{array}$}} & \multicolumn{2}{|l|}{2.1} & \multicolumn{2}{|l|}{1.80} \\
\hline $\operatorname{LSD}(0.05)$ & \multicolumn{2}{|l|}{2.6} & ns & & & & \multicolumn{2}{|l|}{2.9} & 0.31 & \\
\hline Treatment & Cucur & ber crop & & & & Cucuml & ber crop 2 & & & \\
\hline LCivaci & $\begin{array}{l}\text { deforn } \\
(\%)\end{array}$ & & $\begin{array}{l}\text { colour } \\
\text { index }\end{array}$ & $\begin{array}{l}\text { shelf } \\
\text { (days }\end{array}$ & & $\begin{array}{l}\text { deform } \\
(\%)\end{array}$ & & $\begin{array}{l}\text { lour } \\
\text { dex }\end{array}$ & $\begin{array}{l}\text { shelf } 1 \\
\text { (days) }\end{array}$ & \\
\hline $2.5 / 5$ & $<0.1$ & & 6.7 & 12.7 & & 21.2 & 6. & & 11.4 & \\
\hline $3.7 / 5$ & $<0.1$ & & 6.8 & 13.7 & & 22.6 & 6. & & 13.3 & \\
\hline $3.7 / 12.5$ & $<0.1$ & & 6.6 & 11.6 & & 19.8 & 7. & & 14.4 & \\
\hline $5.2 / 5$ & $<0.1$ & & 7.3 & 16.0 & & 19.5 & 7. & & 16.1 & \\
\hline $5.2 / 25$ & $<0.1$ & & 7.3 & 15.8 & & 22.0 & 7. & & 14.4 & \\
\hline $\operatorname{LSD}(0.05)$ & ns & & 0.4 & ns & & ns & 0. & & 2.1 & \\
\hline
\end{tabular}

EC values. This is apparent from the longer shelf life, the higher colour index, and the decrease of russetting and green spot. The higher acid content and the higher refraction with increasing EC value can be considered as improvements of the internal quality. The effect on the vitamin $C$ content was not consistent. 
Table 5. Total water absorption during the experimental period in $1 \mathrm{~m}^{-2}$ and $\mathrm{Na}$ and $\mathrm{Cl}$ absorption expressed in mmol per 1 water absorbed.

\begin{tabular}{|c|c|c|c|c|c|c|c|}
\hline \multirow[t]{4}{*}{ Crop } & \multirow{4}{*}{$\begin{array}{l}\text { Water absorbed } \\
\left(\mathrm{l} \mathrm{m}^{-2}\right)\end{array}$} & \multicolumn{6}{|c|}{$\mathrm{Na}$ and $\mathrm{Cl}$ absorbed $\left(\mathrm{mmol} \mathrm{l}^{-1}\right)$} \\
\hline & & \multicolumn{6}{|c|}{ Concentration of $\mathrm{NaCl}$ in root environment $\left(\mathrm{mmol} \mathrm{l}^{-1}\right)$} \\
\hline & & \multicolumn{2}{|l|}{$<5$} & \multicolumn{2}{|c|}{12.5} & \multicolumn{2}{|l|}{25} \\
\hline & & $\mathrm{Na}$ & $\mathrm{Cl}$ & $\mathrm{Na}$ & $\mathrm{Cl}$ & $\mathrm{Na}$ & $\mathrm{Cl}$ \\
\hline Tomato 1 & 180 & 0.3 & 0.4 & 0.9 & 1.0 & 1.3 & 1.5 \\
\hline Tomato 2 & 480 & 0.6 & 0.7 & 1.1 & 1.4 & 1.4 & 1.7 \\
\hline Sweet pepper & 495 & 0.2 & 0.3 & 0.3 & 0.8 & 0.6 & 1.3 \\
\hline Cucumber 1 & 225 & 0.2 & 0.4 & 1.2 & 1.6 & 2.0 & 2.4 \\
\hline Cucumber 2 & 130 & 0.4 & 0.2 & 1.4 & 2.1 & 3.2 & 5.0 \\
\hline
\end{tabular}

The differences in water uptake of the crops between treatments were marginal. The water absorption averaged over the treatments is listed in Table 5. The absorption of $\mathrm{Na}$ and $\mathrm{Cl}$ by the crops was strongly affected by the concentration of these elements in the root environment, as is shown by the data in Table 5 . Nearly always $\mathrm{Cl}$ was absorbed in greater quantities than $\mathrm{Na}$. The $\mathrm{Na}$ absorption of sweet pepper was generally lower than that of other crops and seemed to be noticeable only during the first months of growing. Later on, there was hardly any absorption of $\mathrm{Na}$ by this crop.

The $\mathrm{Na}$ and $\mathrm{Cl}$ contents of the plant tissues (Table 6) clearly reflect the different absorptions found in the different crops and treatments. The low $\mathrm{Na}$ contents in the sweet pepper tissues are striking.

Table 6. Contents of $\mathrm{Na}$ and $\mathrm{Cl}$ in young fully grown leaves and mature fruits expressed as mmol per $\mathrm{kg}$ dry matter.

\begin{tabular}{|c|c|c|c|c|c|}
\hline \multirow[t]{2}{*}{ Crop } & \multirow[t]{2}{*}{ Tissue } & \multirow[t]{2}{*}{ Element } & \multicolumn{3}{|c|}{$\begin{array}{l}\mathrm{NaCl} \text { concentration in root environment } \\
\left(\mathrm{mmol} \mathrm{l}^{-1}\right)\end{array}$} \\
\hline & & & $<5$ & 12.5 & 25 \\
\hline \multirow[t]{4}{*}{ Tomato } & \multirow[t]{2}{*}{ leaf } & $\mathrm{Na}$ & 41 & 104 & 172 \\
\hline & & $\mathrm{Cl}$ & 77 & 122 & 164 \\
\hline & \multirow{2}{*}{ fruit } & $\mathrm{Na}$ & 31 & 71 & 106 \\
\hline & & $\mathrm{Cl}$ & 136 & 198 & 201 \\
\hline \multirow[t]{4}{*}{ Sweet pepper } & \multirow[t]{2}{*}{ leaf } & $\mathrm{Na}$ & 3 & 3 & 3 \\
\hline & & $\mathrm{Cl}$ & 12 & 17 & 23 \\
\hline & \multirow[t]{2}{*}{ fruit } & $\mathrm{Na}$ & 3 & 6 & 9 \\
\hline & & $\mathrm{Cl}$ & 9 & 24 & 36 \\
\hline \multirow{4}{*}{ Cucumber } & \multirow[t]{2}{*}{ leaf } & $\mathrm{Na}$ & 25 & 93 & 166 \\
\hline & & $\mathrm{Cl}$ & 32 & 154 & 350 \\
\hline & \multirow[t]{2}{*}{ fruit } & $\mathrm{Na}$ & 61 & 172 & 336 \\
\hline & & $\mathrm{Cl}$ & 68 & 197 & 286 \\
\hline
\end{tabular}




\section{Discussion}

In general the marketable yield of the crops tested was not specifically affected by high concentrations of $\mathrm{NaCl}$ in the root environment. This is in agreement with results of other researchers (Maas \& Nieman, 1978). However, the highest $\mathrm{NaCl}$ concentration in the second cucumber crop significantly reduced fruit yield as compared to the highest nutrient concentration. Slight specific yield reductions, though not statistically significant, were also found in the first crop. All this indicates a tendency to specific sensitivity for $\mathrm{NaCl}$, which has also been found for soil grown cucumber (Sonneveld \& van Beusekom, 1974). The slight specific yield reductions of the sweet pepper crops might be explained by the higher percentage of fruits affected by blossom-end rot. Increasing $\mathrm{NaCl}$ concentrations lower the ratio $\alpha_{\mathrm{Ca}}$ ' $\Sigma \alpha_{\text {cation i }}$, and may result in a lower Ca absorption if this ratio decreases (Bennett \& Adams, 1970; Shear, 1975) and induce blossom-end rot. Sweet pepper is very prone to blossom-end rot, as has been found also in experiments with soil grown crops (Sonneveld, 1988a). So, with increasing Na concentrations in the root environment an increase in the $\mathrm{Ca}$ concentration may be necessary for this crop in order to maintain an adequate ion activity ratio.

Maximal yield of rockwool grown crops can be obtained with nutrient concentrations resulting in an EC value of $1.5 \mathrm{dS} \mathrm{m}^{-1}$ in the root environment (Sonneveld, $1988 \mathrm{~b}$ ). This means that if the usual EC value of $3.0 \mathrm{dS} \mathrm{m}^{-1}$ is maintained in the root environment, the difference between 1.5 and $3.0 \mathrm{dS} \mathrm{m}^{-1}$ can be substituted by $\mathrm{NaCl}$ and that $\mathrm{Na}$ and $\mathrm{Cl}$ concentrations of about $12 \mathrm{mmol} \mathrm{l}^{-1}$ are still acceptable. Using water rich in $\mathrm{NaCl}$, the accumulation of $\mathrm{Na}$ will be more critical than that of $\mathrm{Cl}$, as $\mathrm{Na}$ is absorbed less readily than $\mathrm{Cl}$. At a concentration in the root environment of $12 \mathrm{mmol} \mathrm{l}^{-1}$, about $1.0,0.3$ and $1.3 \mathrm{mmol}$ per litre water is absorbed by tomato, sweet pepper and cucumber respectively. Higher $\mathrm{Na}$ concentrations will cause a rapid accumulation and necessitate leaching. The required leaching fraction can be calculated by the following equation:

$$
f_{d}=\frac{N a_{w}+N a_{f}-N a_{c}}{N a_{d}-N a_{c}}
$$

in which $\mathrm{f}_{\mathrm{d}}$ is the leaching fraction, $\mathrm{Na}_{\mathrm{w}}$ the $\mathrm{Na}$ concentration of the irrigation water, $\mathrm{Na}_{\mathrm{f}}$ the increase of the $\mathrm{Na}$ concentration in the irrigation water by impurities of fertilizer addition, $\mathrm{Na}_{\mathrm{c}}$ the $\mathrm{Na}$ absorption of the crop expressed as mmol per litre water absorbed and $\mathrm{Na}_{d}$ the $\mathrm{Na}$ concentration of the drainage water. Guide values for $\mathrm{Na}_{c}$ and $\mathrm{Na}_{\mathrm{d}}$ are traced in the present research. $\mathrm{Na}_{\mathrm{f}}$ can be calculated by the fertilizer impurities. Thus, $\mathrm{f}_{d}$ can be calculated on basis of $\mathrm{Na}_{\mathrm{w}}$.

The data presented for tomato contradict those of Adams (1987). He found that $\mathrm{Na}$ concentrations in the root environment of a soilless culture system could increase up to $37 \mathrm{mmol}^{-1}$ without any yield reduction. His data showed that yields were even slightly higher at $\mathrm{Na}$ concentrations of 22 and $37 \mathrm{mmol} \mathrm{l}^{-1}$ than at low concentrations. Corresponding EC values for low $\mathrm{Na}$ and $37 \mathrm{mmol} \mathrm{l}^{-1} \mathrm{Na}$ were 2.0 
and $6.2 \mathrm{dS} \mathrm{m} \mathrm{m}^{-1}$, respectively. In other words, according to the work of Adams (1987) the salinity threshold value for tomato would be beyond $6.2 \mathrm{dS} \mathrm{m}^{-1}$.

A salinity threshold value for tomatoes between $2.5-2.9 \mathrm{dS} \mathrm{m}^{-1}$, as presented in this paper, is reasonably in agreement with values generally found. In a review of crop salt tolerance, Maas \& Hoffman (1977) gave a threshold value based on saturation extracts of $2.5 \mathrm{dS} \mathrm{m}^{-1}$. This value can be converted to a value of $3.8 \mathrm{dS} \mathrm{m}^{-1}$ in the soil solution (Sonneveld et al., 1990). The contradiction referred to may be caused by differences in growing conditions. Under climatical conditions promoting vegetative growth, tomato plants may grow too vigorously and then high salinity will improve fruit formation. The data of Adams (1987) suggest such an effect. In our data the low SYD value of tomato crop 1 (Table 3) may also be explained by a vigorous growth, for this crop starting in full summer showed such a development.

\section{References}

Adams, P., 1987. The test of raised salinity. The Grower 107 (2) Supplement: 23-27.

Bennett, A. C. \& F. Adams, 1970. Calcium deficiency and ammonia toxicity as separate causal factors of $\left(\mathrm{NH}_{4}\right)_{2} \mathrm{HPO}_{4}$ - injury to seedlings. Soil Science Society of America Proceedings 34: 255-259.

Graves, C. J., 1971. The nutrient film technique. Horticultural Review 5: 1-44.

Maas, E. V. \& G. J. Hoffman, 1977. Crop salt tolerance - Current assessment. Journal of the Irrigation and Drainage Division 103, No IR2: 115-134.

Maas, E. V. \& R. H. Nieman, 1978. Physiology of plant tolerance to salinity. In: Crop tolerance to suboptimal land conditions. ASA Special Publication No 32, p. 277-299. US Salinity Lab ARS/ESDA, Riverside, California.

Shear, C. B., 1975. Calcium-related disorders of fruits and vegetables. HortScience 10: 361-365.

Sonneveld, C. \& J. van Beusekom, 1974. The effect of saline irrigation water on some vegetables under glass. Acta Horticulturae 35: 75-86.

Sonneveld, C., 1988a. The salt tolerance of greenhouse crops. Netherlands Journal of Agricultural Science 36: 63-73.

Sonneveld, C., 1988b. Rockwool as a substrate in protected cultivation. In: T. Takakura (Ed.), Horticulture in High Technology Era, Proceedings International Symposium on High Technology Protected Cultivation (Tokyo), p. 173-191.

Sonneveld, C. \& N. Straver, 1989. Nutrient solutions for vegetables and flowers grown in water or substrates. Series: Voedingsoplossingen Glastuinbouw, No 8, $35 \mathrm{pp}$. Glasshouse Crops Research Station, Naaldwijk.

Sonneveld, C., J. van den Ende \& S. S. de Bes, 1990. Estimating the chemical compositions of soil solutions by obtaining saturation extracts or specific $1: 2$ by volume extracts. Plant and Soil 122: 169-175. 